\title{
The impact of impact studies
}

\author{
J. W. Hedgreth \\ Marine Science Center, Oregon State University; \\ Newport, Oregon, USA
}

EXTRAIT: L'impact des études d'impact. Le 1ier janvier 1970 le «National Environmental Policy Act» est devenu une loi aux Etats-Unis, et a été renforcé par des dispositions judiciaires. Cette loi rend obligatoire, entre autres, la présentation d'informations concernant l'effet, sur l'environnement, des travaux publics ou privés projetés et autorisés par le gouvernement fédéral, ainsi que la suggestion de projets alternatifs. Un des évènements qui a influencé l'adoption de cette législation est le rejet de pétrole survenu à Santa Barbara en janvier 1969. Quant à l'environnement marin, la disposition la plus importante relative aux prévisions d'impact concerne l'étude des stations côtières où peuvent être situées des décharges de déchets ou des centrales nucléaires ou de désalination. Quoique beaucoup d'études entreprises par lindustrie aient été superficielles, les enquêtes publiques ont fait apparaître la nécessité d'une application critique des techniques écologiques connues depuis les travaux classiques de LORENZ (1863), brièvement évoqués par HERDMan (1920) et Elmhrost (1932). L'impact des études d'impact pourra non seulement relever le niveau des études sur l'environnement marin, mais aussi clarifier l'application actuellement assez incohérente, par des écologistes pragmatiques, de concepts théoriques aussi contestables que ceux de la diversité ou stabilité des communités.

\section{INTRODUCTION}

If GoETHE were writing in our times he would probably have written a very different conclusion to Faust. Perhaps he would have Faust redeemed not by public works, but through preventing environmental degradation. Or, he might have attributed Faust's difficulties to failure to file an impact statement for his salt marsh reclamation project. In that context, however, GoETHE attributed to Mephistopheles a rather modern sounding prediction that nature will in the end dispose of man's best laid plans: "Die Elemente sind mit uns verschworen, und auf Vernichtung läuft's hinaus."

Be that as it may, as late as 1906 that excellent and environmentally conscious geologist Nathaniel Southgate Shaler, in one of the first books to call attention to the finite capacity of the earth, remarked with regrettable complacency on the eventual filling up of marshlands and tideflats to serve the needs of man's ever expanding population (SHALER 1906). So, "there are in all the great lands vast areas of lakes, swamps, and marshes awaiting the skillful labor which has won Holland from the sea. The largest opportunity of profit is in such brave combats with the incomplete work of nature" (Shaler 1906 pp. 18-19). But, in all justice to SHaler, we should 
remind readers that he expected the birth rate to decrease with increasing pressure on the environment, and that his vision of "when the earth has been brought under the effective control of man" did not include our vastly expanded power technology with its implicit threat to warm up the very earth itself.

Today we are aware of these implications in the United States, even if some people hidden deep in our corporate woodwork still think the deluge is safely a generation off. For the moment, as a national policy, we are demanding that anyone who seeks to do something that will have an effect upon the environment, the natural world around us, make a study of what his project will do to the environment, and then file a report on these studies and a statement analyzing these possible effects.

\section{ECOLOGY BY LEGISLATION}

When the Congress of the United States passed the National Environmental Policy Act on New Year's Day, 1970, it was obvious that many members of the Congress had little idea exactly what they were doing. The act declares a "national policy which will encourage productive and enjoyable harmony between man and his environment; to promote efforts which will prevent or eliminate damage to the environment and biosphere and stimulate the health and welfare of man; to enrich the understanding of the ecological systems and natural resources important to the $\mathrm{Na}$ tion". This act made ecology mandatory, for it plainly states that all agencies of the Federal Government shall provide a detailed statement on the environmental impact of the proposed action. Judicial decisions have subsequently emphasized the mandatory intent of Congress and further, in the famous Calvert Cliffs decision of July 23, 1971, the ruling was made that the Atomic Energy Commission itself is not immune from the provisions of the act (SELECTED materials on the Calvert Cliffs decision 1972). While this legislation, known as NEPA, is very strong in both wording and intent, many branches of the bureaucracy and their associated vested interests, especially the atomic power industry, are mounting the barricades to stop its interference with their business, and hopefully to nullify it with qualifying amendments and counter measures.

It is possible that some qualification of NEPA will be made for projects already under construction, but the basic philosophy of NEPA will be hard to change in our present climate in which attorneys have become more effective proponents of sound ecology than employees of governmental conservation agencies, or even professional ecologists, and the bad effects of material progress are becoming more obvious to everyone. It should be remembered in this context that one of the circumstances that prompted the enactment of NEPA was the Santa Barbara oil leak of January, 1969.

This requirement of impact studies that in practice must meet the scrutiny of hungry lawyers advised sub rosa by some of our better ecologists, should have an especially salutary influence upon field studies in the coastal zone, especially in those intertidal situations that are the favored sites for atomic power plants in the United States. So far, these studies, intended to produce "base line" information, have not been impressive, primarily because of the reluctance of the industries and agencies 
concerned to finance them adequately, and secondarily because the work has been carried out by consultants and assistants lacking the training or understanding necessary for such work. Yet, insofar as studies relative to possible environmental changes in the shore zone are concerned, we have known what should be done for more than a hundred years, and for at least fifty years have had some sound advice available even in plain English.

It can be said that objective marine ecology had its beginnings, not with PETERsen in the Danish coastal waters, but with J. R. Lorenz of Vienna in the Gulf of Quarnero. His great work, "Physicalische Verhältnisse und Vertheilung der Organismen im Quarnerischen Golfe" (1863) is even today a much more thorough basic study than most current impact studies in the United States. It lacks only one thing, quantitative data on the density and abundance of the common organisms, although the numbers of species were indicated (for other comments on this unique work see RIEDL 1964). The value of repeated observations in the same locality was emphasized by KrNG \& Russel (1909) who advocated a series of measurements of variables which included many of those recorded by Lorenz, but still without recognizing the need for quantitative data for the species. Nevertheless they were aware of one of the difficulties inherent in accumulating a significant mass of objective data: "The working of such a system is not a task for isolated workers, but one which demands, for each part of the coast, the cooperation of a number of observers, who shall collect, record, and compare results"' (p. 252).

The importance of numbers of shore animals and plants, although with especial reference to their values for the productivity of the sea, was apparently first emphasized by Heroman (1920), who nevertheless cautioned against blithe extrapolation: "But one must not go too far. Let all the figures be based upon actual observation. Imagination is necessary in science, but in calculating a population of even a very limited area it is best to believe only what one can see." A year or so before, but inspired by Herdman, MaYne (1918) reported on numbers per unit area on a rocky shore.

The example for all subsequent diving studies was set by GisLen (1930) who in 1927-29 carried out extensive in situ studies in the Gullmar Fjord, carefully enumerating and weighing the larger, conspicuous species. Here at last we have both weights and numbers for the epibioses of the rocky substratum, reported and analyzed in detail. This classic work should be read by all diving biologists; it is obvious that far too many, at least in the United States, have not heard of it. GISLEN, however, emphasized the subtidal regions; it was ElmHrRst (1932) who called attention to the signifcance of and need for more quantitative data on shore animals, and concluded with this encouraging paragraph: "All that is needed for such work is (1) an accurate knowledge of the characters of the few species to be particularly investigated; (2) opportunity to visit seasonally one of a few selected localities to count or take samples; (3) the patience to measure specimens and tabulate properly the readings taken; and (4) due care in drawing conclusions from the data obtained" (p. 8).

Yet it was in this year 1932 that the late T. A. STEPHENSON started his survey of the intertidal zonation of the coasts of South Africa. In all, this work, and the succeeding studies in America by T. A. and AnNe Stephenson, is strikingly deficient 
in quantitative information of the sort that can be applied to subsequent studies of the same localities. Such counts as there are seem to be based on numbers seen per hour or on a transect of unspecified length. To be sure, these studies give us a good impression of the character of the seashores studied. But they cannot be used with confidence in the context of our need to detect and predict changes in the environment. His principal disciple, J. R. LEwIS, in his work on the rocky intertidal zones of British shores (LEWIS 1964), comments upon the dynamic nature of the shore with especial reference to populations; his work demonstrates, nevertheless, the limits of the primarily subjective Stephensonian approach to littoral ecology.

A somewhat more sophisticated approach to field data is that of tabulating relative densities or abundances in terms of "more than 50", or "less than 10" per unit area, and so on. The most elaborate application of this approadh is described by Ballantine (1961). While this does provide more coherent data than the artistic approach (which I confess to having used myself, e.g. in the Galapagos, HedGPETH 1969), it does depend upon the observations being made by the same person to be reasonably comparable from year to year.

Numbers were beginning to creep into intertidal ecology, especially with reference to barnacles in the 1950's, with such studies as those of Southward (1953), and SOUTHWARD \& ORTON (1954), but it would not appear that ElmHrRst's advice was seriously followed until the studies of interactions between barnacles and their predators by ConNeli $(1961 \mathrm{a}, \mathrm{b})$. Connell's procedure included careful measuring and counting of barnacles of unit areas; measurements of areas occupied were accomplished by drawings on glass plates over the study plots. An obvious step beyond this procedure would be the accumulation of precisely located photographs with the same lens systems and focal distances from established marks over a period of years, and it would not be surprising to see this method applied in such a way as to make it possible to feed the photographs directly into a data bank. From then on, of course, the computer will provide all the necessary answers. Nevertheless, any field study of value requires careful advance consideration of how the data are to be obtained and how they may be put into the computer. We are still a long way from the ideal situation in which a television scanner linked to a computer will simply peer at the environment and produce neatly interpreted results. Inasmuch as this utopia is still in the distant future, we must rely on our own wits. What is required for meaningful field observations in the context of environmental impact concerns has been succinctly summarized (from other sources, it should be said) by my friend Evan C. Evans, now engaged in studies of Pearl Harbor and Kaneohe Bay in the Hawaiian Islands:

1. Thou shalt frame the ecological question with a null hypothesis.

2. Thou shalt so construe thy industry in the fields to falsify thy null hypothesis.

3. Thou shalt be duplicate, yeah verily even triplicate, in all that thou dost.

4. Thine industry shall be offered to the statistical priests to receive blessing thereof.

5. Thy labors shall be artful both in the fields and in thy cell.

6. Thou shalt make thyself safe against the cunning of the devil who is called pollution.

7. Thou shalt not seek before the question for it is in vain. 
The commandments, it need hardly be said, were inspired by some unfortunate examples of poorly done environmental studies, one of them a review of the effects of the oil leak at Santa Barbara. In the same part of the world considerable effort has been devoted to the study of the possible effects on the marine environment of the massive sewer outfalls from the great Southern California megalopolis. After consideration of several of these, a group of advanced students and their instructors at Scripps Institution of Oceanography expressed general dissatisfaction and suggested, as a control on such studies, that the plans for such work be submitted at the outset to "external, independent, objective referees" (McGowan et al. 1969). Dissatisfaction with inadequate field studies is increasing, and the problem has been discussed in several editorials in the journal "Ecology", especially with reference to adequate communication between lawyers and ecologists (CURLIN 1972) and the ethics and competence of ecologists, especially those engaged in consulting (AUERBACH 1972, STARK 1972). This concern may ultimately lead to the establishment of panels or review boards by the Ecological Society of America, or its activist arm, The Institute of Ecology, to control the quality of this work. It is difficult to legislate quality in science, however, and much of the present concern about impact statements is how they should be interpreted or evaluated (see DitTon \& GOODALE 1972), with the unfortunate implication that in many cases the letter of the law may be served while the environment is allowed to deteriorate. Nevertheless a slow process has been set in motion that should in time improve the quality of research in field ecology as well as increase the competence of the investigators. The principal stumbling blocks to this hope of improvement are the draconian time scale set for many environmental studies, and the reluctance of people to undertake hard work.

\section{THE SEARCH FOR MAGIC NUMBERS}

While no one would deny the need for field studies, especially in such an obvious situation as in situ studies in relation to pollution or environmental manipulation by man, the complexity, difficulty and expense of such studies have led some to appear to emphasize the greater efficacy of laboratory tests in providing information to predict environmental change. It may be obvious to an ecologist that this procedure may not always produce reliable base line information, and a suggestive study by ROMERIL (1971) indicates there may be real differences between the result involving retention time of substances in organisms in nature as contrasted with those in a flow through experimental system. In defense of his laboratory protocol, TARzwell (1971) stated that "we do not advocate the use of standard test animals in our routine bioassays", but he seemed to have some difficulty making himself clear as to exactly what he was trying to do (see pp. 285, 287, 289 of this recorded discussion), inasmuch as he emphasized the use of four standard organisms to test relative toxicity. What is not plain, perhaps, is whether the individual organisms subjected to tests are from long suffering and perhaps impervious laboratory stocks or specimens freshly selected from wild populations. That some of these organisms have survived as long as they have in nature, let alone the laboratory, suggests they are not the best surrogates 
for evaluating environmental effects on other species. Fundulus beteroclitus, for example, can survive the tender ministrations of many amateur aquarists as well as chance additions to its biotope from the diuretic activity of cows. In any event, when we are concerned with the potential impact upon organisms in the environment, the results of laboratory tests upon laboratory acclimated stocks can be of little signifcance. One hardly needs Occam's razor to shave the fuzz off this sort of reasoning.

The search for simple approaches and magic numbers that may be obtained with relative ease has led some pragmatic ecologists down the primrose path of theoretical ecology. Perhaps unaware of the highly speculative basis for such concepts as diversity and stability, they have oversimplified the idea of diversity indexes to suggest that a high diversity index is ipso facto indication of the well being or more natural condition of a biocoenosis and consequently the number can be interpreted as an abstract value of the state of pollution. As a corollary to this, it seems implicit, at least in some studies, that alteration of an index derived from the kinds and quantities of species in a given situation may indicate the degree of pollution (PEARson et al. 1967). This may not necessarily be true, and one would hope that as these impact studies increase in numbers and quality, there will be more awareness of the theoretical nature of current diversity indexes. This is especially true where different staffs of investigators have used different suites of organisms from year to year to derive a diversity index or where attempts are made to compare numerical indexes based on samples from different times of the year. Examples of mistakes of this kind could be cited, but the vast bulk of "soft paper" reports in which they occur are not generally accessible. From the viewpoint of academic ecology, Margalef (1968, p. 20) emphasizes the theoretical nature of diversity indexes by reminding us that "all points in an ecosystem have unique properties, and it is a bad beginning to assume that one is working with samples from a uniform universe". If one must assume a uniform universe, it follows that no diversity index can be more than suggestive since, as HeNDrICKSON \& EHRLICH (1971) make clear, the assumptions for such diversity indexes cannot be met in any but a stable, monospecific and asexual system. These assumptions are: (1) All individuals of the same species are identical. (2) All pairs of differing species are equally different.

This is not to suggest that diversity indexes based upon coherent systematic groups, e.g. diatoms or foraminiferans have no value in field ecology, although it should be remembered that a limited or paucispecific grouping does not necessarily indicate a stressed or unstable situation. If this were so, such ecosystems as sewage treatment plants would not work. What is obvious is that a diversity index per se is not the philosopher's stone and may indeed represent a great deal of unnecessary labor if the data are inconsistent to begin with. Even in an area of reasonably consistent conditions (Tomales Bay, California) where the changes in diversity have been studied for a decade, the significance of the diversity index is considered theoretical and subject to testing by experimental field studies (JoHnson 1970, 1971). In this study of a gradational mosaic of organisms in several adjacent sediment types, there was a significant influence upon the diversity index by ubiquitous species, common to the range of environments: "Thus an index of diversity is found to be very sensitive to the occurrence of two ubiquitous species and therefore does not contain 
much ecological information about the local assemblage as a whole" (JoHnson \& SmrTH, unpublished).

As a result of these studies, JoHnson \& SMith, state: "In the absence of any other criteria, many engineers have attempted to use an index of species diversity as a measure of the health of the community. In general, within a particular ecosystem, high diversity is indicative of the high stability of the system. A substantial drop in diversity would be indicative of a disturbance. Obviously such a single parameter of a complex system must be cautiously interpreted. Ecosystems vary widely in absolute diversity. In no sense are intertidal communities less healthy than subtidal communities because they tend to be at lower levels of diversity. We have seen how the occurrence of a few species (the ubiquitous species) can have a very strong influence on an index of diversity. Finally, it should be pointed out that in order to calculate an index of diversity it is necessary to have the same kind of data that can be used for a more sophisticated analysis of the community."

Unfortunately the officers of regulatory bodies are not so cautious, and may be in danger of legislating ecological concepts into rigid procedures. One may wonder what the state of the environment would be today if thirty or forty years ago decisions had been made on the basis of a few $\mathrm{pH}$ readings, as if these readings represented constant or stable values of profoundly esoteric significance. Yet everyone is busy compiling "guidelines", often without any real understanding of the significance of the recommendations. To an ecologist who knows that all species must have some function in a system or at least somehow influence others, the definition of a species as "important" that by implication includes all species does not seem as outrageous as it may be to the hearing officers who will eventually have to evaluate the information: "A species, whether animal or plant, is important if it is rare or endangered, if it is of specific scientific interest, or if it is necessary to the well being of some significant species (e.g., a food chain component) or to the balance of the ecological system." Such a definition would indeed mark the sparrow's fall.

It is clear that if we are to carry out impact studies according to the guidelines being suggested by such regulatory agencies as the AEC and state water quality boards, the ideal members of the study team would have to be LORENZ and GISLÈN. Yet, were we to obtain the services of persons of such competence, we would undoubtedly have immediate disagreement on such commandments, that are currently being proposed by the California Water Resources Control Board, as:

Two benthic samples will be taken at each station using an "orange peel dredge" or "ponar dredge" to sample the sediments.

The following shall be determined and used to evaluate the species diversity (Simpson's or MARgalef's Measure of Diversity, or Information Measure of an Infinite Population), density and biomass.

Sampling for zooplankton will be conducted by using two vertical tows from bottom to surface at each station.

The danger of legislating a current fashion in ecology, or one dimly remembered by an administrator who perhaps did not do so well in the course, is obvious to anyone, or should be.

At the same time there seems to be little effort to apply the concepts of fisheries 
to ecological impact. It must be granted that for most species we have little idea of the population structure, replacement, etc., all those things that in old fashioned Shelfordian ecology used to be called "biotic potential", that would enable us to estimate the sustainable yield of a given population. But on the other hand we have estimated this ex post facto for many major fisheries stodks. It would be an interesting exercise if the fisheries industry were obliged to file impact statements estimating, on the basis of present knowledge, the percentage of the population they should be permitted to take in advance. Of course in some regulated fisheries this is exactly what is done. Yet, the suggestion that an industrial installation requiring large volumes of cooling water, e.g. an atomic power plant, should be regarded as a stationary predator levying upon the population that chances into its intake pipes, is not taken too kindly. Perhaps it is because it assumes a hundred percent loss to organisms in the water, or this point of view brings out too clearly the continuous drain upon the populations concerned. Yet that is exactly what we are talking about, the taking by man of living stodks, either from human consumption as in a fisheries, or as part of his "trade off" for producing paper, power or other products for his own needs.

\section{CONCLUSIONS}

Probably the real meaning of our concern over the impact of our industrial activities on the environment is our realization that we are in danger of causing irreversible changes to populations of organisms that in some way influence our own well being on this small planet. From the more practical viewpoint, however, the requirement that the potential effect of projects on the environment be estimated has produced a confused ferment of ecological studies, in which still untested theories may be frozen into bureaucratic procedures and inadequately trained personnel may be canonized as consulting ecologists. Yet for most of the environments of principal concern, including the near shore and shallow sea, there are excellent and venerable examples of how to conduct studies which would satisfy all the criteria of impact studies. Unfortunately they require more common sense, willingness to work and, in this day, funds, than seem readily available. However, we cannot afford to permit the operation of a sort of GRESHAM's law in ecological work in which mediocre and topical research would prevail over more rigorous, soundly based environmental studies, if indeed the requirement for impact studies is to live up to its philosophical implications.

\section{SUMMARY}

1. On January 1, 1970 the National Environmental Protection Act became law in the United States, and has been further strengthened by judicial interpretations. This act requires, among other things, a presentation of information to justify the effect of projects on the environment of both public and private works controlled by the permit process of the federal government, and to suggest alternatives. One 
of the events which influenced passage of this legislation was the Santa Barbara oil spill of January 1969.

2. Insofar as the marine environment is concerned, the most significant activity related to the requirement for impact statements is the study of coastal situations where waste outfalls, atomic power plants or desalination plants may be located. Although many of the studies sponsored by industry have been cursory, the need for critical application of ecological techniques known since the classical studies of LORENZ (1863) and touched upon in brief notes by HERDMAN (1920) and ELmHIRst (1932) has become obvious through the public hearing process.

3. The impact of impact studies may not only be to raise the standards of environmental studies in the sea, but also to clarify the present somewhat incoherent application by pragmatic ecologists of such debatable theoretical concepts as diversity and community stability.

\section{LITERATURE CITED}

AuERBACH, S. I., 1972. Ecology, ecologists and the E.S.A. Ecology 53, 205-207.

BaLlanting, W. J., 1961. A biologically-defined exposure scale for the comparative description of rocky shores. Fld Stud. 1 (3), 1-19.

ConNet., J. H., 1961a. Effects of competition, predation by Thais lapillus, and other factors on natural populations of the barnacle Balanus balanoides. Ecol. Monogr. 31, 61-104.

- 1961b. The influence of interspecific competition and other factors on the distribution of the barnacle Chthamalus stellatus. Ecology 42, 710-723.

CurLtn, J. W., 1972. Courts, ecology and environmental planning. Ecology 53, 373-374.

Ditton, R. B. \& Goodale, T. I. (Eds.), 1972. Environmental impact analysis: philosophy and methods. Univ. Wisconsin, Sea Grant Publ. Off., Madison, Wis., 171 pp.

Elmhirst, R., 1932. Quantitative studies between tide marks. Glasg. Nat. 1932, 1-8.

Grsten, T., 1930. Epibioses of the Gullmar Fjord, P. 2: Marine sociology (Kristinebergs Zoologiska Station, 1877-1927). SkrSer. K. svenska VetenskAkad. 1930 (4), 1-380.

HEDGPETH, J. W., 1969. An intertidal reconnaissance of rocky shores of the Galapagos. Wasmann J. Biol. 27 (1), 1-24.

Hendrickson, J. A. \& Ehrlich, P. R., 1971. An expanded concept of "Species diversity". Notul. Nat. 439, 1-6.

Herdman, W. A., 1920. Notes on the abundance of some common marine animals. J. Linn. Soc. (Zool.) 34, 247-259.

Johnson, R. G., 1970. Variations in diversity within benthic marine communities. Am. Nat. 104, (937), 285-300.

- 1971. Animal sediment relations in shallow water benthic communities. Mar. Geol. 11, 93-104.

- \& SMTTH, E. H., 1971. Predicting faunal changes in marine environments. Environmental Study of 'Tomales Bay for the Water Quality Office Environmental Protection Agency $\mathbf{5}$, 1-35 (Proj. \# 18050 DFP).

KING, L. A. L. \& Russell, E. S., 1909. A method for the study of the animal ecology of the shore. Proc. R. phys. Soc. Edinb. 17, 225-253.

LEwis, J. R., 1964. The ecology of rocky shores. English Universities Press, London, 323 pp.

Lorenz, J. R., 1863. Physicalische Verhältnisse und Vertheilung der Organismen im Quarnerischen Golfe. Kais. Kön. Hof- und Staatsdr., Wien, 379 pp.

McGowan, J. A., 1970. The ecology and oceanography of sewer outfalls. Scripps Institution of Oceanography, La Jolla, 22 pp. (S.I.O. Ref. Nr. 70-18). 
Margalef, R., 1968. Perspectives in ecological theory. Univ. of Chicago Press, Chicago, Ill., $111 \mathrm{pp}$.

Mayne, C., 1918. Report of the Edward Forbes Exhibitions. A. Rep. Liverpool mar. biol. Commn. 32, 10-13.

Pearson, E. A., Storrs, P. N. \& Selieck, R. E., 1967. Some physical parameters and their significance in marine waste disposal. In: Pollution and Marine Ecology. Ed. by T. A. OLson \& F. J. Burgess. Interscience Publs., New York, 297-315.

RIEDL, R., 1964. 100 Jahre Litoralgliederung seit Josef Lorenz, neue und vergessene Gesichtspunkte. Int. Revue ges. Hydrobiol. 49, 281-305.

Romeril, M. G., 1971. The uptake and distribution of $65 \mathrm{Zn}$ in oysters. Mar. Biol. 9, 347-354.

SELECTED materials on the Calvert Cliffs decision, its origin and aftermath. 1972. (Joint Committee on Atomic Energy.) Congress of the United States. Government Printing Office, Washington, D. C. 92,1-676.

Shater, N. S., 1906. Man and the earth. Fox, Duffield $\&$ Co., New York, 240 pp.

STARK, N., 1972. Ecology and ethics. Ecology 53, 1-2.

Stephenson, T. A. \& Stephenson, A., 1972. Life between tide marks on rocky shores. W. $\mathrm{H}$. Freeman, San Francisco, 425 pp.

TARZWELL, C., 1971. Toxicity of oil and oil dispersant mixtures in aquatic life. In: Water pollution by oil. Ed. by P. Hepple. Institute of Petroleum, London, 263-272.

Author's address: Dr. J. W. HEDGPETH

Marine Science Center

Oregon State University

Newport, Oregon 97365

USA 